\title{
Effectiveness Of Learning Media Using Argument Driven Inquiry (ADI) Learning Model To Increase Students' Learning Outcomes And Self Efficacy
}

\author{
Tukiran \\ dept. of Chemistry \\ Universitas Negeri Surabaya \\ Surabaya, Indonesia \\ tukiran@unesa.ac.id
}

\author{
Choirun Nikmah \\ dept. of Chemistry \\ Universitas Negeri Surabaya \\ Surabaya, Indonesia
}

\author{
Harun Nasrudin \\ dept. of Chemistry \\ Universitas Negeri Surabaya \\ Surabaya, Indonesia
}

\begin{abstract}
This This research aimed to find the effectiveness of a theaching instrument in order to increase students' self efficacy and learning outcomes using Argument Driven Inquiry (ADI) teaching instrument on the electrolyte and nonelectrolyte. The test was applied to the 30 students of grade $X-3$ and X-4 in Senior high school 7 of Surabaya. Development model of this teaching method used the three stages 4D model from Thiagarajan (define, design, develop). The application stage in the class used Pre-test and Post-test Group Design, the evaluation used the self efficacy questionnaire, motivation questionnaire and pretest -posttest problems. The result found that the increase of average students' self efficacy was 0.56 in medium category for experiment class and 0.08 in low category for control class, and the average increase of motivation was 0.6. In medium category for experiment class and 0.12 in low category for control class,. The average increase of learning outcomes was 0.7 in high category for experiment class and 0.5 in medium category for control class. Based on the data analysis, the developed teaching instrument effectively increases the students' self-efficacy and learning outcomes.
\end{abstract}

Keywords-effectiveness, Argument Driven Inquiry, SelfEfficacy

\section{INTRODUCTION}

Education is a foundation of developing nations' potential and civilization. The learning process is hoped to develop the students' potential, lead the students to have a strong religion foundation, character, self-control, smartness, attitude and life skill. The 2013 curriculum is hoped to develop the education. One of them is to change the paradigm of passive students to become active students. The studying activities are aimed to practice the student in finding information and knowledge [23].

The result of interview with one of the chemistry teachers on November 20, 2018 shows the learning process is still teacher center and the students are the information recipients. The learning process is often done in the class room. The practical of chemistry is seldom done. The questionnaire before the result found that $85.7 \%$ students were interested in practical. From $91.4 \%$ students stated that the teacher is seldom in using scientific method in learning process. The next is $80 \%$ students do not dare to ask to the teacher in the learning process. The students also don't have confidence in gaining high score in chemistry. The previous statement is supported by the result of pre research questionnaire which shown that only 28.5 students are confident in gaining high score while the rest were not sure about their score of chemistry. The another result also found that 48.5 students were accustomed to give attention to the teachers explanation and the students had lack of confidence.

What must the students have are self-confidence, adaptable, cognitive skill, smartness and a ability to act in a stressing situation. One thing that worth to try to develop this self-efficacy is by using ADI learning method.

\section{METHOD}

The research was conducted by using the structure of Pretest and Post-test Group Design. There were two designs for two groups and grouped in random method. Then the two groups did the pretest and posttest after the treatment. The design of the research was defined into the followings:

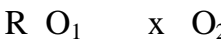
$\begin{array}{llll}\mathrm{R}_{3} & \mathrm{O}_{3} & \mathrm{O} & \end{array}$

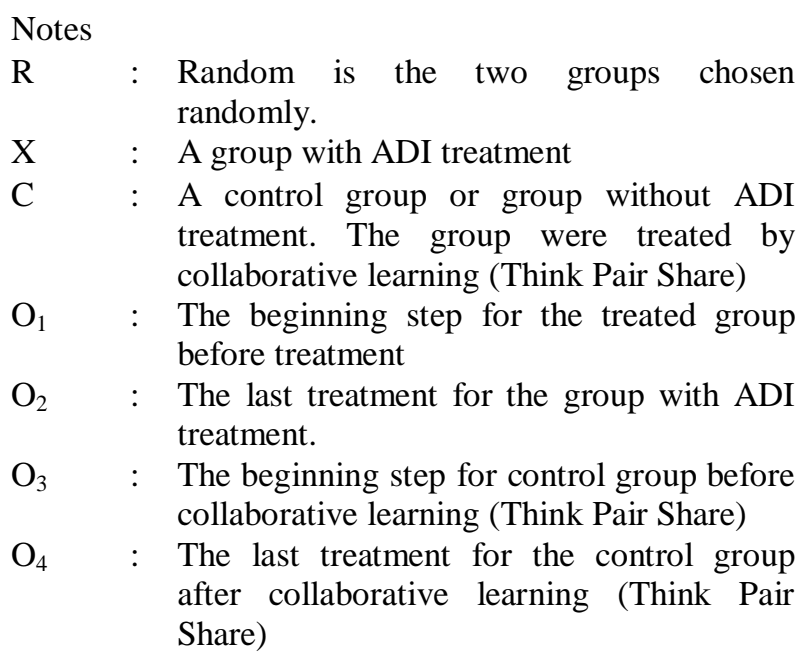

The pretest and posttest were concept understanding, learning motivation, and self efficacy. The pretest was done before ADI treatment while the posttest was done after the ADL learning Method. 


\section{RESEARCH RESULT AND DISCUSSION}

\section{A. Self Efficacy Questionnaire}

The Self Efficacy Questionnaire was filled by 30 students of X-3 and X-4. The scoring was aimed to know the level of students self efficacy. The data of students' self efficacy ability of each aspect is shown in the table 1 .

\begin{tabular}{cccc}
\multicolumn{4}{c}{ TABLE I. INCREASED SELF EFFICACY IN EVERY } \\
ASPECT
\end{tabular}

Based on the table 1 above, the score of average students self efficacy raise before the learning process of each aspects to the control class is 0.08 . The average raise of each student is 0,08 and the score of class experiment is 0.56 . The average raise to each individual is 0.56 .

The increase of students self efficacy is measured by using N-Gain. The result is the increase of each aspect of individual is 0.08 in the control class and 0.56 in the treated class which the increase in the control class is in the low category and the conclusion of self efficacy increase in the control class is low. The increase of self efficacy gained is proper to the Farah et.al statement (2018) which stated that the lack of self efficacy can be solved by using ADI learning model.

\section{B. Motivation Questionnaire}

The Motivation questionnaire was filled by 30 students of $\mathrm{X}-3$ and $\mathrm{X}-4$. The scoring is designed to find the increase of students learning motivation. The following is the increase of students' motivation in the form of graphic:

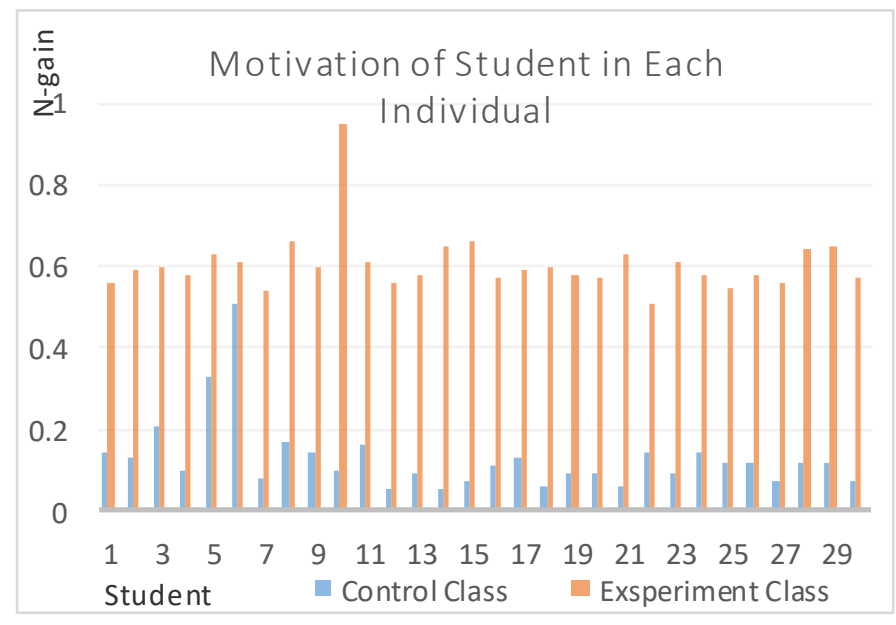

Fig. 1. Motivation of student in each individual

The first picture shows that different in the level of students' motivation increase for each individual in the control class and treated class. In the control class the average $\mathrm{N}$-gain score is 0.12 with the low category increase while the treated class the $\mathrm{N}$-gain is 0,6 in average.

The increase of students learning motivation of each individual is measured by using $\mathrm{N}$ - gain which the result shows 0.12 increase in control class and 0.60 in treated class. The increase of control class is low and it can be concluded that the increase of students motivation in the control class in low.

Bandura (1994) revealed that self efficacy had important role in shaping a self motivation [11]. Self efficacy had a significant connection with motivation, academic option, changes and achievement. However, those all depend on how each individual in controlling themselves in doing their tasks [21].

\section{Learning Outcomes}

The increase of students self efficacy is hoped to increase the outcomes of the study as well. The knowledge test is given before (pretest) and after (posttest). The result of the learning outcomes test on the 30 students of X-3 and $\mathrm{X}-4$ is presented in the following picture 2:

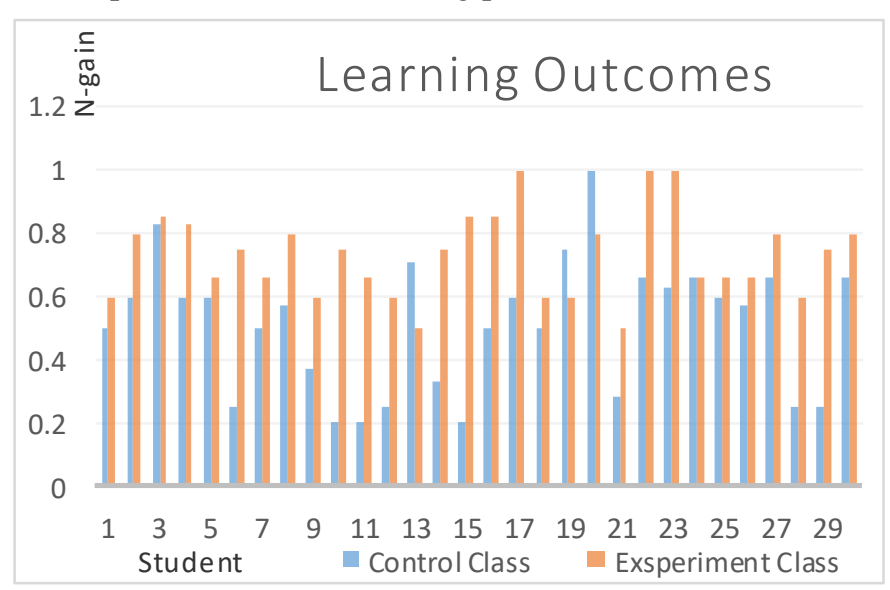

Fig. 2. Learning Outcomes

The picture 2 shows that the students gain higher score in the posttest than pretest for both classes (control class and treated class). The increase is accumulated by using $\mathrm{N}$-gain. The treated class average score is 0.73 with high criteria and the students are stated completed classically or 100\% complete. In the control class, the average of $\mathrm{N}$ - gain score is 0.5 but $46.6 \%$ students are incomplete. So, the control class is not completed in classical.

The result of pretest and posttest gained shows the increase of cognitive learning outcome and the increase is calculated by using $\mathrm{N}$-gain. The score is 0.5 for the control class and 0.73 for treated class. The score of control class is $46.4 \%$ students are not complete so that can be stated that the control class is not complete classically and the treated class is completed classically.

The increase is the learning outcome calculated with $\mathrm{N}$ gain shows that the development of teaching instrument of ADI. The instrument is effective in increase cognitive aspect of self-efficacy. It is proved from the increase in the cognitive learning outcome of treated class is higher than 
control class. The process of cognitive is needed in forming a strong self efficacy to face situation which needs analytic thinking to act in the right way [11].

\section{CONCLUSION}

Based on the research done in Senior High School 7 of Surabaya, the different self efficacy, students learning result, and students motivation of treated class using ADI learning method and the control class using collaborative learning of Think Pair Share are found. The increase of self efficacy, learning outcome, and students learning motivation of the treated class is higher that control class. As conclusion, the learning instrument which is developed effectively could increase students self efficacy and students learning outcome.

\section{ACKNOWLEDGMENT}

The researcher would say thank you to Utiya Azizah, Bambang Sugiarto and Achmad Lutfi, as the validators for validated the teaching instruments developed by the researcher.

\section{REFERENCES}

[1] Kementrian Pendidikan dan Kebudayaan. 2013. Pengembangan Kurikulum 2013. Jakarta: Paparan Menteri Pendidikan dan Kebudayaan RI.

[2] Hairida, Marhaeny. 2012. Self efficacy dan Prestasi Belajar Siswa Dalam Pembelajaran IPA Kimia. Jurnal Pendidikan IPA. Tanjungpura: Universitas Tanjungpura.

[3] Erika, Farah., dan Praharani, B.K. 2017. Innovative Chemistry Learning Model to Improve Argumentation Skills and Self-Efficacy. IOSR Journal of Research and Method in Education (IOSR-JRME). Vol.7, 62-68.

[4] Erika, Farah., Praharani, B.K., Supardi, dan Tukiran. 2018 Development Of a Graphic Organizer-baesed Argumentation Learning (GOAL) Model For Improving The Self-efficacy and Ability to Argue of Chemistry Teachers Candidates. World Transaction on Enginering and Technology Education. Vol.16, No.2.

[5] Westwood, (2008). What Theacher Need to Know about Theaching Method. Australia: Acer Press
[6] Daryanto. 2014. Pendekatan pembelajaran saintifik kurikulum 2013. Yogyakarta: Gava Media.

[7] Thiagarajan, S., Semmel, D., S and Semmel, M., I. 1974. Instructional Development for Training Teachers of Expectional Children. Minneapolis: Leadership Training Institute / Special Education, University of Minnesota

[8] Riduwan 2012 Skala Pengukuran Variabel-variabel Penelitian (Bandung: Alfabeta)

[9] Bandura, A. 1997. Self Efficacy; The Exercise of Control. New York: W.H. Freeman and Company.

[10] Prastowo, A. 2015. Bahan Ajar Inovatif. Yogyakarta: Diva Press.

[11] Bandura, A. 1994. Encyclopedia of human behavior. 4: 71-81. Tersedia pada http://www.uky.edu. Diakses 15 maret 2019.

[12] Zimmerman. 2000. Self-Efficacy: An Essential Motive to Learn. Contemporary Educational Psychology. New York: Graduate School and University Center of City University of Newyork.

[13] Andriani, Y, A. 2015. Peningkatan Penguasaan Konsep Siswa Melalui Pembelajaran Argument Drivent Inquiry Pada Pembelajaran IPA Terpadu di SMP kelas VII. Edusains. Vol 7, pp, 114-120.

[14] Anita, Karyasa, dan Tika. 2013. E-Journal Program Pascasarjana Universitas Pendidikan Ganesha "Pengaruh Model Pembelajaran Kooperatif Tipe Group Investigation (GI) Terhadap Self-Efficacy Siswa" Vol. 3.

[15] Annisa, Hemani, dan Taufik. 2016. International Conferences of Mathematics and Science Educatioan "Argument-Driven Inquiry (ADI): The Way to Develop Junior High Schools Student's Argumentation Skills in Science Learning" Vol. 57.

[16] Zehra dan Nermin. 2009. The Effect of a Guided Inquiry Method on Preservice Teachers' Science Teaching Self-Efficacy Beliefs. Journal of Turkish Science Education. Volume 6, Issue 2.

[17] Katelhut, D,J. 2007. The Impact of Student Self efficacy on Scientific Inquiry Skills: An Exploratory Investigation in River City, a Multi-user Virtual Environment. Journal of Science Education and Technology.

[18] Sampson, V., Schleigh, S. 2016. Scientific Argumentation in Biology Book: 30 classroom activities. USA: NSTA press.

[19] Hake, R.R. 1999. American Educational Research Association's Division D, Measurement and Research Methodology: Analyzing Change/Gain Scores. USA: Woodland Hills.

[20] Arikunto, S. 1997. Penilaian Program Pendidikan Edisi III. Bina aksara. Jakarta.

[21] Pajaes, F. (1996). Self-efficacy beliefs in academic settings. Review of Educational Research, 66(4), 543-578. doi:10.3102/00346543066004543.

[22] Kementerian Pendidikan dan Kebudayaan. (2014). Permendikbud RI No. 104 Tahun 2014 tentang penilaian hasil belajar oleh pendidik pada pendidikan dasar dan pendidikan menengah. Jakarta: Kemendikbud. 